\title{
Oxidative DNA Damage Induced by Pirarubicin, an Anthracycline Anticancer Agent, in the Presence of Copper(II)
}

\author{
HIDEKI MIZUTANI $^{1}$, AYANO NISHIMOTO ${ }^{1}$, SAKI HOTTA ${ }^{1}$, KENJI IKEMURA ${ }^{1,2}$, \\ MASANORI IMAI $^{1}$, DAISUKE MIYAZAWA ${ }^{1}$, KINYA OHTA $^{1}$, YOSHIAKI IKEDA ${ }^{1}$, \\ TOHRU MAEDA ${ }^{1}$, MASAE YOSHIKAWA ${ }^{1}$, YUSUKE HIRAKU ${ }^{3}$ and SHOSUKE KAWANISHI ${ }^{4}$ \\ ${ }^{1}$ College of Pharmacy, Kinjo Gakuin University, Nagoya, Japan; \\ ${ }^{2}$ Department of Pharmacy, Mie University Hospital, Tsu, Japan; \\ ${ }^{3}$ Department of Environmental and Molecular Medicine, Mie University Graduate School of Medicine, Tsu, Japan; \\ ${ }^{4}$ Faculty of Pharmaceutical Sciences, Suzuka University of Medical Science, Suzuka, Japan
}

\begin{abstract}
Background/Aim: One mechanism of the anticancer action of anthracyclines is believed to be oxidative DNA damage. Previously, we reported that doxorubicin induced oxidative DNA damage in the presence of $\mathrm{Cu}(\mathrm{II})$. However, the mechanism of pirarubicin-induced oxidative DNA damage has not been well clarified. Materials and Methods: DNA damage by pirarubicin in the presence of $\mathrm{Cu}(\mathrm{II})$ was analyzed using pBR322 plasmid DNA. $\mathrm{O}_{2}{ }^{-}$derived from pirarubicin in the presence of $\mathrm{Cu}(\mathrm{II})$ was detected by cytochrome $\mathrm{c}$ reduction. Results: Pirarubicin induced DNA damage in the presence of $\mathrm{Cu}(I I)$. Scavenger experiments suggest that reactive species are generated from $\mathrm{H}_{2} \mathrm{O}_{2}$ and $\mathrm{Cu}(\mathrm{I})$. Pirarubicin induced $\mathrm{O}_{2}{ }^{-}$ production in the presence of $\mathrm{Cu}(\mathrm{II})$. Conclusion: These findings suggest that pirarubicin plus $\mathrm{Cu}(\mathrm{II})$ induces oxidative DNA damage in a similar manner to doxorubicin, and $\mathrm{Cu}(\mathrm{II})$ mediated oxidative DNA damage may serve as a common mechanism for antitumor effects of anthracyclines.
\end{abstract}

Pirarubicin (4'-O-tetrahydropyranyl doxorubicin, THP; Figure 1A) is an anthracycline which was synthesized from doxorubicin (Figure 1B) by Umezawa et al. in 1979 (1). THP has a potent anticancer activity against a variety of solid cancer types as well as blood cancer $(2,3)$. The cytotoxicity of THP against cultured tumor cells was found

This article is freely accessible online.

Correspondence to: Hideki Mizutani, Ph.D., College of Pharmacy, Kinjo Gakuin University, Moriyama-ku, Nagoya 463-8521, Japan. Tel: +81 527987458, Fax: +81 527980754, e-mail: mizu@kinjou.ac.jp and Shosuke Kawanishi, Ph.D., Faculty of Pharmaceutical Sciences, Suzuka University of Medical Science, Suzuka, Mie 5138670, Japan. Tel: +81 593400568, Fax: +81 593681271, e-mail: kawanisi@suzuka-u.ac.jp

Key Words: Pirarubicin, DNA damage, ROS, copper. to be equal or superior compared to that of doxorubicin, and the cardiotoxicity of THP was less than that of doxorubicin in hamsters $(4,5)$. THP is clinically approved in Japan for treatment of cancer of the head and neck, stomach, upper urinary tract, uterus and ovary, as well as acute leukemia and malignant lymphoma. Recently, it was reported that THP appeared to be less cardiotoxic than daunorubicin in the treatment of childhood acute lymphoblastic leukemia in a clinical trial (6). THP drug delivery systems developed by Maeda et al. have high tumor-targeting efficiency by enhanced permeability and retention effect $(7,8) . N-(2-$ Hydroxypropyl)methacrylamide (HPMA) copolymerconjugated THP was also highly effective for a patient with stage IV prostate cancer and extensive lung and bone metastases (9). Therefore, THP has recently once again gained attention in the field of cancer chemotherapy.

The anticancer action of anthracyclines is believed to be through DNA damage. DNA damage is caused by topoisomerase II inhibition, DNA intercalation and reactive oxygen species (ROS) generation (10). Recently, we reported that THP induced apoptosis through the generation of ROS (11). However, the mechanism of THP-induced DNA damage has not well been clarified. In this study, we investigated the mechanism of THP-induced DNA damage using plasmid DNA in the presence of copper (Cu) (II). In addition, we examined $\mathrm{O}_{2}{ }^{--}$production induced by THP in the presence of $\mathrm{Cu}(\mathrm{II})$.

\section{Materials and Methods}

Materials. Pirarubicin, superoxide dismutase (SOD; 3,000 U/mg from bovine erythrocytes), catalase $(45,000 \mathrm{U} / \mathrm{mg}$ from bovine liver) and cytochrome c (from equine heart) were purchased from Sigma Chemical Co. (St. Louis, MO, USA). Plasmid DNA (pBR322) and DNA gel loading dye (6x) were from Toyobo Co. (Osaka, Japan). Copper chloride $\left(\mathrm{CuCl}_{2} \cdot 2 \mathrm{H}_{2} \mathrm{O}\right)$ was from Nacalai Tesque Co (Kyoto, Japan). Diethylenetriamine- $N, N, N$ ', $N$ ", $N$ '”-penta- 
A

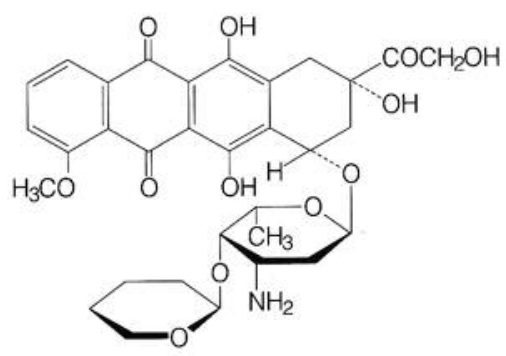

Pirarubicin
B<smiles>COc1cccc2c1C(=O)c1c(O)c3c(c(O)c1C2=O)CC(O)(C(=O)OCO)C[C@H]3O[C@H]1C[C@@H](N)[C@H](O)[C@H](C)O1</smiles>

Figure 1. Chemical structure of pirarubicin and doxorubicin.

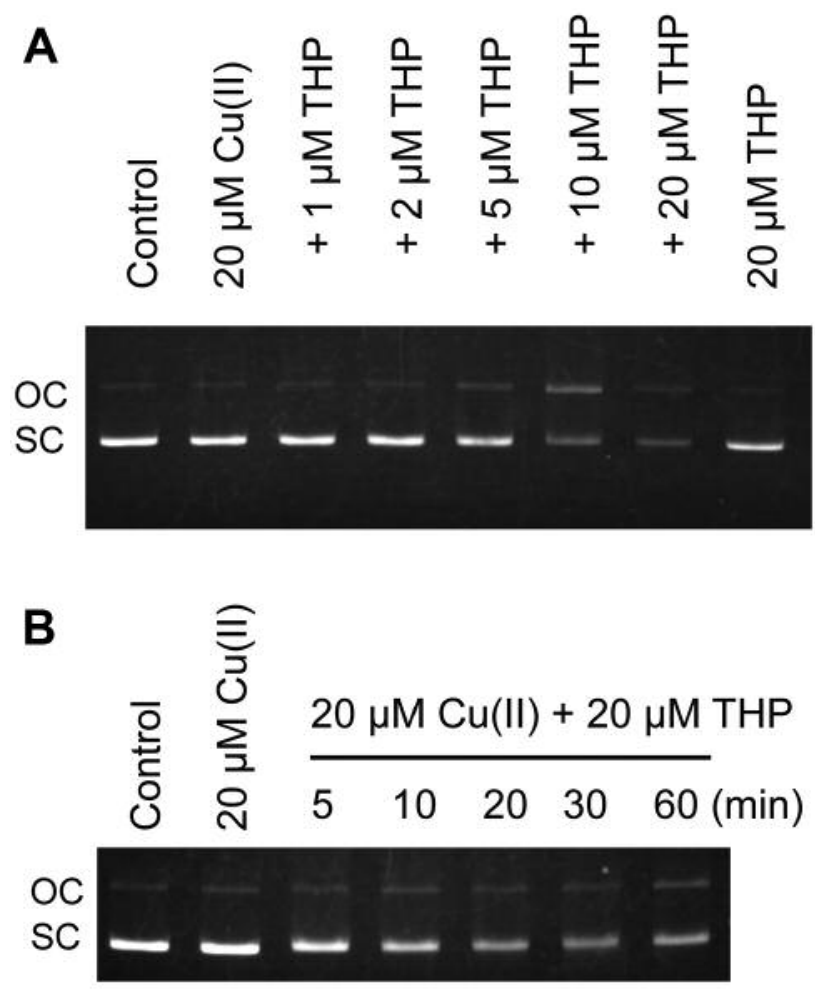

Figure 2. Agarose gel electrophoretic patterns for the cleavage of plasmid DNA pBR322 treated with pirarubicin (THP). A: The plasmid DNA was treated with the indicated concentrations of THP in the presence of $20 \mu \mathrm{M}$ $\mathrm{CuCl}_{2}$ at $37^{\circ} \mathrm{C}$ for $1 \mathrm{~h}$. B: The plasmid DNA was treated with $20 \mu \mathrm{MTHP}$ in the presence of $20 \mu \mathrm{M} \mathrm{CuCl}{ }_{2}$ at $37^{\circ} \mathrm{C}$ for the indicated times. The supercoiled (SC) and open circular (OC) forms of DNA are indicated.

acetic acid (DTPA) and bathocuproinedisulfonic acid were from Dojin Chemicals Co. (Kumamoto, Japan). 3-(Methylthio) propionaldehyde (methional) was from Tokyo Kasei Co. (Tokyo, Japan). All other chemicals used were of the highest purity commercially available.
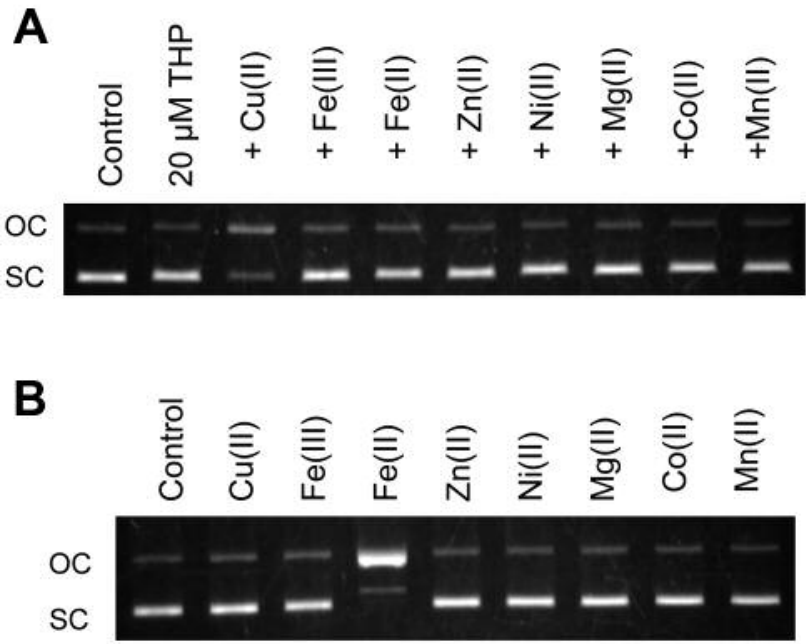

Figure 3. Agarose gel electrophoretic patterns for the cleavage of plasmid DNA pBR322. A: The plasmid DNA were treated with $20 \mu \mathrm{M}$ pirarubicin $(T H P)$ in the presence of $20 \mu \mathrm{M}$ metal at $37^{\circ} \mathrm{C}$ for $1 \mathrm{~h} . \mathrm{B}$ : The plasmid DNA were treated with $20 \mu \mathrm{M}$ metal at $37^{\circ} \mathrm{C}$ for $1 \mathrm{~h}$. Where indicated, $\mathrm{CuCl}_{2}, \mathrm{FeCl}_{3}, \mathrm{FeSO}_{4}\left(\mathrm{NH}_{4}\right)_{2} \mathrm{SO}_{4}, \mathrm{ZnSO}_{4}, \mathrm{NiSO}_{4}, \mathrm{MgCl}_{2}$, $\mathrm{CoCl}_{2}$ or $\mathrm{MnCl}_{2}$ was added. The supercoiled (SC) and open circular (OC) forms of DNA are indicated.

Analysis of DNA damage by THP in the presence of $C u(I I)$. The standard reaction mixture placed in a $1.5 \mathrm{ml}$ Eppendorf microtube contained THP, $20 \mu \mathrm{M} \mathrm{CuCl}_{2}$, pBR322 plasmid DNA $(0.2 \mu \mathrm{g} /$ tube $)$ in $50 \mu \mathrm{l}$ of $10 \mathrm{mM}$ sodium phosphate buffer ( $\mathrm{pH} 7.8$ ) containing $5 \mu \mathrm{M}$ DTPA, a chelating agent, to remove trace amounts of contaminating metals. After incubation at $37^{\circ} \mathrm{C}$ for $60 \mathrm{~min}$, the DNA gel loading dye was added to the reaction mixture and the reacted DNA was electrophoresed on a $0.7 \%$ agarose gel containing ethidium bromide. The obtained DNA gels were analyzed by using UV transilluminator (12).

Analysis of DNA damage by THP in the presence of metals. The reaction mixture was placed in a $1.5 \mathrm{ml}$ Eppendorf microtube and contained $20 \mu \mathrm{M}$ THP, $20 \mu \mathrm{M}$ metals $\left[\mathrm{CuCl}_{2}, \mathrm{FeCl}_{3}\right.$, 
A

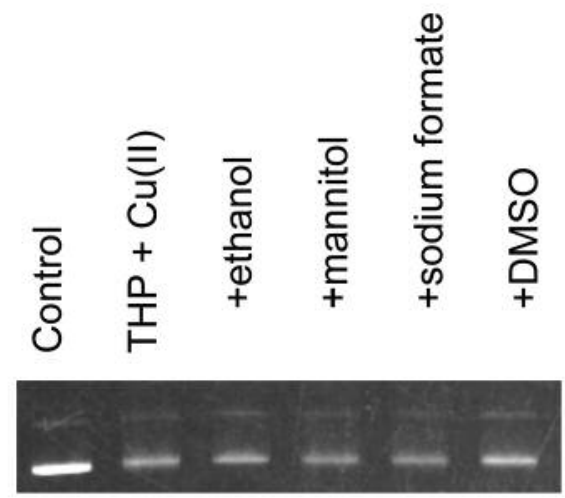

B

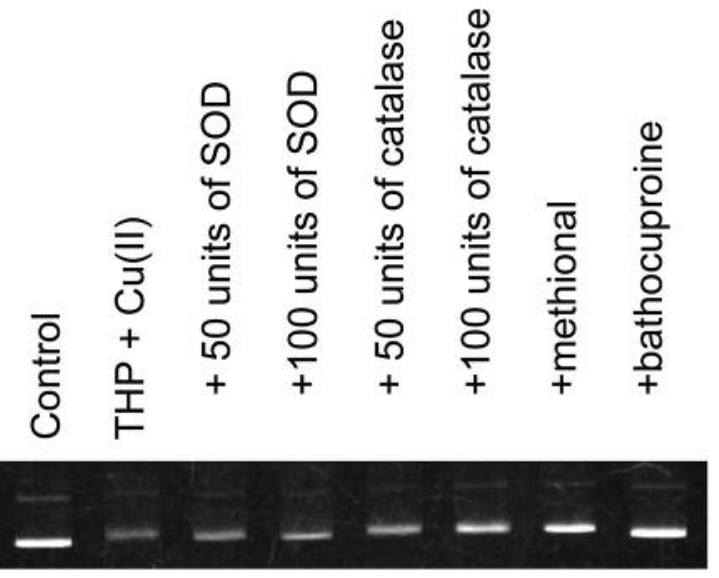

Figure 4. Effects of reactive oxygen species (ROS) scavengers and bathocuproine on DNA cleavage induced by THP in the presence of $\mathrm{Cu}(\mathrm{II})$. The plasmid DNA was treated with $20 \mu \mathrm{M}$ pirarubicin (THP) in the presence of $\mathrm{Cu}(\mathrm{II})(20 \mu \mathrm{M})$ at $37^{\circ} \mathrm{C}$ for $1 \mathrm{~h}$. Where indicated, $1.7 \mathrm{M}$ (10\%) ethanol, $0.1 \mathrm{M}$ mannitol, $0.1 \mathrm{M}$ sodium formate, $0.7 \mathrm{M}(10 \%)$ $D M S O, 50$ or 100 units of superoxide dismutase (SOD), 50 or 100 units of catalase, $0.1 \mathrm{M}$ methional or $50 \mu \mathrm{M}$ bathocuproine was added. The supercoiled (SC) and open circular (OC) forms of DNA are indicated.

$\mathrm{FeSO}_{4}\left(\mathrm{NH}_{4}\right)_{2} \mathrm{SO}_{4}, \mathrm{ZnSO}_{4}, \mathrm{NiSO}_{4}, \mathrm{MgCl}_{2}, \mathrm{CoCl}_{2}$ or $\left.\mathrm{MnCl}_{2}\right]$, and pBR322 plasmid DNA $(0.2 \mu \mathrm{g} /$ tube $)$ in $50 \mu \mathrm{l}$ of $10 \mathrm{mM}$ sodium phosphate buffer ( $\mathrm{pH} 7.8$ ) containing $5 \mu \mathrm{M}$ DTPA. After incubation at $37^{\circ} \mathrm{C}$ for $60 \mathrm{~min}$, the DNA gel loading dye was added to the reaction mixture and the reacted DNA was electrophoresed on a $0.7 \%$ agarose gel containing ethidium bromide. The obtained DNA gels were analyzed using UV transilluminator (12).

Analysis of effects of ROS scavengers and bathocuproine on DNA damage by THP in the presence of $\mathrm{Cu}(I I)$. The reaction mixture was placed in a $1.5 \mathrm{ml}$ Eppendorf microtube and contained $20 \mu \mathrm{M}$ THP, $20 \mu \mathrm{M} \mathrm{CuCl}_{2}$, and pBR322 plasmid DNA $(0.2 \mu \mathrm{g} /$ tube $)$ in $50 \mu \mathrm{l}$ of $10 \mathrm{mM}$ sodium phosphate buffer ( $\mathrm{pH} 7.8$ ) containing $5 \mu \mathrm{M}$ DTPA with ROS scavengers and bathocuproine $(50 \mu \mathrm{M})$. ROS scavengers included $1.7 \mathrm{M}(10 \%)$ ethanol, $0.1 \mathrm{M}$ mannitol, $0.1 \mathrm{M}$ sodium formate, $0.7 \mathrm{M}(10 \%)$ DMSO, 50 or 100 units of SOD, 50 or 100 units of catalase, or $0.1 \mathrm{M}$ methional. After incubation at $37^{\circ} \mathrm{C}$

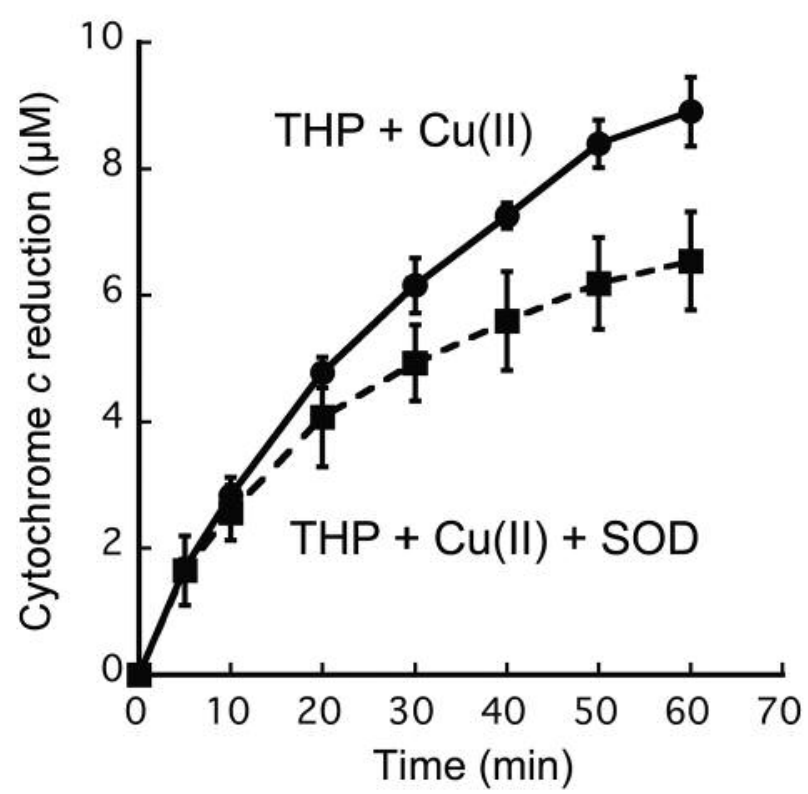

Figure 5. Time course of cytochrome c reduction during the incubation of pirarubicin (THP) in the presence of $\mathrm{Cu}(\mathrm{II})$. The reaction mixture contained $100 \mu \mathrm{M}$ cytochrome $c, 20 \mu \mathrm{M}$ THP in the presence $20 \mu \mathrm{M}$ $\mathrm{Cu}(\mathrm{II})$ in $10 \mathrm{mM}$ sodium phosphate buffer ( $\mathrm{pH} 7.8$ ) containing $2.5 \mu \mathrm{M}$ diethylenetriamine- $N, N, N$ ',$N$ ", $N$ "-penta-acetic acid (DTPA). A maximum absorption at $550 \mathrm{~nm}$ was measured at $37^{\circ} \mathrm{C}$ with a UV-visible spectrophotometer. The actual amount of $\mathrm{O}_{2}{ }^{--}$generation was calculated by subtracting absorbance with $100 \mathrm{U} / \mathrm{ml}$ superoxide dismutase (SOD) from that without SOD at $550 \mathrm{~nm}\left(\varepsilon=21.1 \times 10^{3} \mathrm{M}^{-1} \mathrm{~cm}^{-1}\right)$. The data were expressed as means $\pm S D(n=3)$.

for $60 \mathrm{~min}$, the DNA gel loading dye was added to the reaction mixture and the reacted DNA was electrophoresed on a $0.7 \%$ agarose gel containing ethidium bromide. The obtained DNA gels were analyzed using UV transilluminator (12).

Detection of $\mathrm{O}_{2}^{--}$derived from THP in the presence of $\mathrm{Cu}(\mathrm{II})$. To detect $\mathrm{O}_{2}{ }^{-}$generation from THP, $100 \mu \mathrm{M}$ cytochrome $\mathrm{c}$ was added to the reaction mixture, which contained $20 \mu \mathrm{M}$ THP and $20 \mu \mathrm{M}$ $\mathrm{Cu}$ (II) in $1 \mathrm{ml}$ of $10 \mathrm{mM}$ sodium phosphate buffer ( $\mathrm{pH} 7.8$ ) containing $2.5 \mu \mathrm{M}$ DTPA. Maximum absorption at $550 \mathrm{~nm}$ due to ferrocytochrome $\mathrm{c}$ formed by ferricytochrome $\mathrm{c}$ reduction was measured at $37^{\circ} \mathrm{C}$ with a UV-visible spectrophotometer (UV-1700; Shimadzu, Kyoto, Japan). The actual amount of $\mathrm{O}_{2}{ }^{-}$generation was calculated by subtracting the absorbance obtained using $100 \mathrm{U} / \mathrm{ml}$ SOD from that without SOD at $550 \mathrm{~nm}\left(\varepsilon=21.1 \times 10^{3} \mathrm{M}^{-1} \mathrm{~cm}^{-1}\right)(13)$.

\section{Results}

THP-induced DNA damage in the presence of $\mathrm{Cu}(\mathrm{II})$. Figure 2 shows agarose gel electrophoretic patterns for damage of plasmid DNA pBR322 treated with THP. The intensity of DNA damage increased depending on THP concentrations in the presence of $\mathrm{Cu}$ (II) (Figure 2A). THP induced weak DNA damage at $5 \mu \mathrm{M}$ and apparent strong DNA damage above 


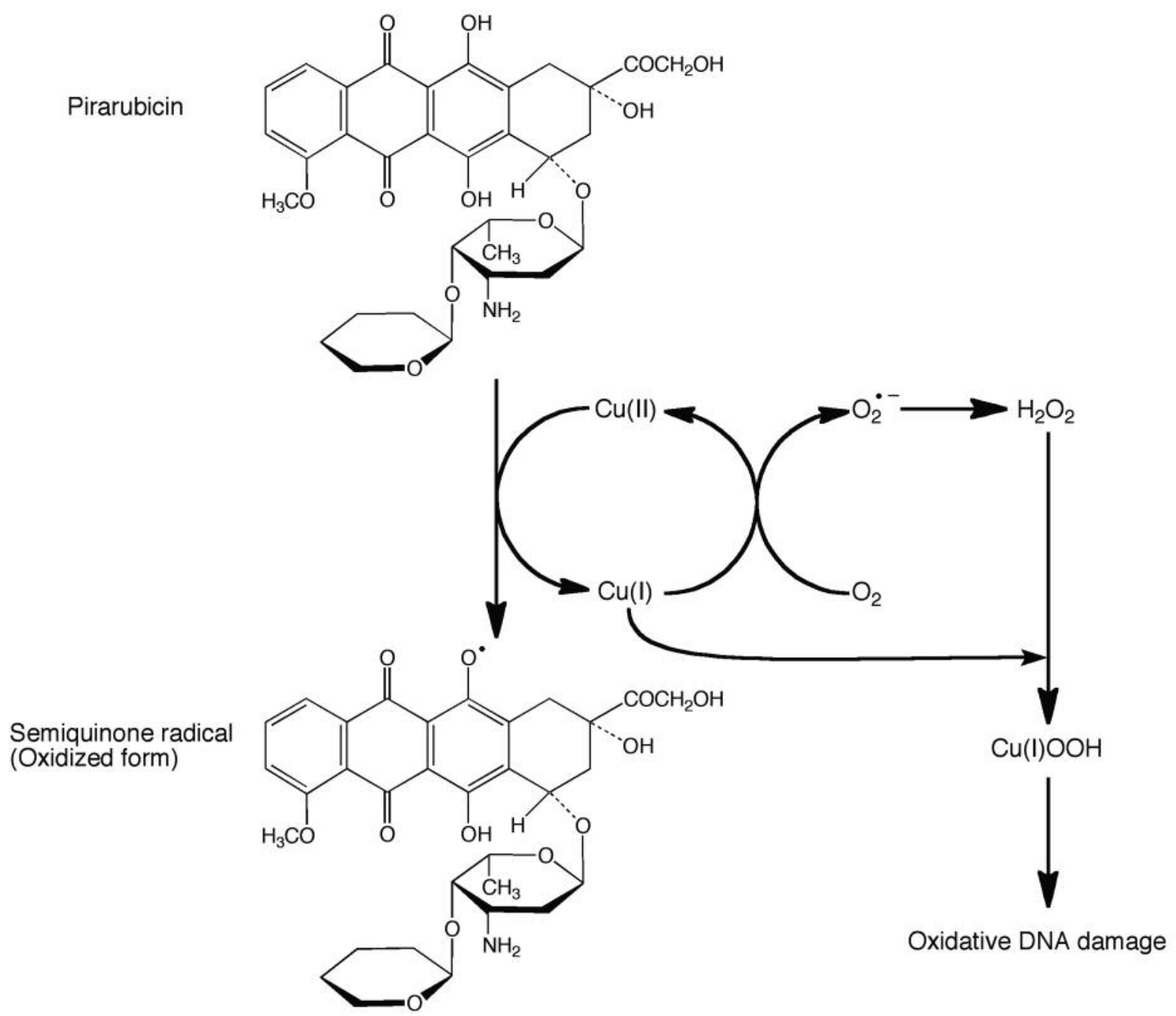

Figure 6. Proposed mechanisms for oxidative DNA damage induced by pirarubicin in the presence of $\mathrm{Cu}(\mathrm{II})$.

$10 \mu \mathrm{M}$ in the presence of $\mathrm{Cu}$ (II). $\mathrm{Cu}$ (II) or THP alone did not induce DNA damage. The intensity of THP-induced DNA damage increased depending on incubation time in the presence of $\mathrm{Cu}(\mathrm{II})$ (Figure 2B). THP induced apparent DNA damage above $20 \mathrm{~min}$ in the presence of $\mathrm{Cu}$ (II). On the other hand, THP did not cause DNA damage in the presence of $\mathrm{Fe}(\mathrm{III}), \mathrm{Fe}(\mathrm{II}), \mathrm{Zn}$ (II), Ni(II), Mg(II), Co(II) or Mn(II) (Figure $3 \mathrm{~A})$. However, since $\mathrm{Fe}(\mathrm{II})$ alone induced DNA damage, it is suggested that THP may chelate Fe(II) $(14,15)$ (Figure 3B).

Effects of ROS scavengers and bathocuproine on DNA damage by THP in the presence of $\mathrm{Cu}(I I)$. Figure 4 shows the effects of ROS scavengers and bathocuproine on DNA damage induced by THP in the presence of $\mathrm{Cu}$ (II). Typical -OH scavengers, ethanol, mannitol, sodium formate and DMSO, showed little or no inhibitory effect on DNA damage
(Figure 4A). SOD and catalase had inhibitory effects on DNA damage and DNA damage was completely inhibited by methional and bathocuproine (Figure 4B).

Detection of $\mathrm{O}_{2}{ }^{-}$derived from THP in the presence of $\mathrm{Cu}(I I)$. Figure 5 shows $\mathrm{O}_{2}{ }^{\circ-}$ production by THP in the presence of $\mathrm{Cu}(\mathrm{II})$. The incubation of cytochome $\mathrm{c}$ in the presence of THP and $\mathrm{Cu}$ (II) led to a time-dependent increase in the cytochome $\mathrm{c}$ reduction. When SOD was added, the amount of cytochrome $\mathrm{c}$ reduction decreased, suggesting the generation of $\mathrm{O}_{2}{ }^{-}$. From these results, $\mathrm{O}_{2}{ }^{--}$production by $20 \mu \mathrm{M}$ THP was approximately $2.5 \mu \mathrm{M}$ in the presence of $20 \mu \mathrm{M} \mathrm{Cu}$ (II). The inhibition of cytochome $c$ reduction by SOD was only partial. This result suggests that there are the other $\mathrm{O}_{2}{ }^{-}$-independent mechanisms of cytochrome $\mathrm{c}$ reduction, probably mediated by $\mathrm{Cu}(\mathrm{I})$ (16). 


\section{Discussion}

In this study, we demonstrated that THP induced oxidative damage to plasmid DNA in the presence of $\mathrm{Cu}(\mathrm{II})$ in a cellfree system. SOD and catalase had inhibitory effects on DNA damage, suggesting the involvement of $\mathrm{O}_{2}{ }^{--}$and $\mathrm{H}_{2} \mathrm{O}_{2}$. Bathocuproine, which prevents the activation of $\mathrm{H}_{2} \mathrm{O}_{2}$ by stabilizing $\mathrm{Cu}(\mathrm{I})(17,18)$, completely inhibited DNA damage, suggesting the involvement of $\mathrm{Cu}(\mathrm{I})$. As typical ${ }^{\circ} \mathrm{OH}$ scavengers did not show inhibitory effects on DNA damage, it is suggested that free ${ }^{\circ} \mathrm{OH}$ does not play an important role in DNA damage. DNA damage was completely inhibited by methional, which scavenges not only ${ }^{\circ} \mathrm{OH}$ but also other radicals such as metal-oxygen complexes (19). Therefore, it is considered that ROS such as $\mathrm{Cu}(\mathrm{I}) \mathrm{OOH}$ are involved in $\mathrm{Cu}(\mathrm{II})$-mediated DNA damage. Moreover, we demonstrated that THP generated $\mathrm{O}_{2}{ }^{--}$in the presence of $\mathrm{Cu}(\mathrm{II})$, suggesting that THP and $\mathrm{Cu}(\mathrm{II})$ generated $\mathrm{Cu}(\mathrm{I})$, that reacted with $\mathrm{O}_{2}$ to generate $\mathrm{O}_{2}{ }^{--}$and subsequently $\mathrm{H}_{2} \mathrm{O}_{2}$.

We previously demonstrated that doxorubicin induced oxidative DNA damage in the presence of $\mathrm{Cu}(\mathrm{II})$ through oxidation of its p-hydroquinone moiety by copper ion (16). THP has a same aglycone moiety of doxorubicin (Figure 1). Therefore, THP appears to induce oxidative DNA damage in the presence of copper in a similar manner to doxorubicin. We propose the mechanism of THP-induced oxidative DNA damage to be as follows: THP undergoes $\mathrm{Cu}$ (II)-mediated oneelectron oxidation at the para-OH group to generate $\mathrm{Cu}(\mathrm{I})$ and the semiquinone radical. $\mathrm{Cu}(\mathrm{I})$ reacts with $\mathrm{O}_{2}$ to generate $\mathrm{O}_{2}{ }^{-}$ and subsequently $\mathrm{H}_{2} \mathrm{O}_{2}$. $\mathrm{Cu}(\mathrm{I})$, which is bound to DNA, interacts with $\mathrm{H}_{2} \mathrm{O}_{2}$, resulting in the formation of a DNAcopper-hydroperoxo complex [DNA-Cu(I)OOH] (Figure 6). Although typical ${ }^{\circ} \mathrm{OH}$ scavengers had no inhibitory effect on DNA damage, ${ }^{\circ} \mathrm{OH}$ may participate in DNA damage through the formation of DNA-Cu(I)OOH, which can release ${ }^{\circ} \mathrm{OH}$ in the vicinity of DNA. ${ }^{\circ} \mathrm{OH}$ immediately attacks an adjacent constituent of DNA, before it is scavenged by ${ }^{\circ} \mathrm{OH}$ scavengers. In addition, our recent study demonstrated that THP induces apoptosis through the generation of $\mathrm{H}_{2} \mathrm{O}_{2}$ (11). Furthermore, it is reported that normal mouse hepatocytes were found to contain $40 \mu \mathrm{M}$ of copper in the nucleus and 120 $\mu \mathrm{M}$ of copper in the cytosol by synchrotron X-ray fluorescent imaging $(20,21)$. The affinity of DNA for copper ions appears to be greater than for other essential metal ions $(21,22)$.

These findings suggest that THP in the presence of copper may induce oxidative DNA damage in cells. We reported that anticancer agents (doxorubicin, hydroxyurea, procarbazine, cyclophosphamide and dacarbazine) induced oxidative DNA damage in the presence of copper in a cell-free system (16, 23-26). Several previous reports stated that anthracyclines induced ROS generation and oxidative DNA damage in the presence of iron $(15,27,28)$, whereas we demonstrated that copper also plays an important role in DNA-damaging activity of anthracyclines. Therefore, $\mathrm{Cu}(\mathrm{II})$-mediated oxidative DNA damage may be a common mechanism for the antitumor effects of anthracyclines.

\section{Acknowledgements}

This work was supported by JSPS KAKENHI Grant Number 25460229 and $16 \mathrm{~K} 08420$.

\section{References}

1 Umezawa H, Takahashi Y, Kinoshita M, Naganawa H, Masuda $\mathrm{T}$, Ishizuka $\mathrm{M}$, Tatsuta $\mathrm{K}$ and Takeuchi $\mathrm{T}$ : Tetrahydropyranyl derivatives of daunomycin and adriamycin. J Antibiot 32: 10821084,1979

2 Shibata Y, Hara T, Kasahara S, Yamada T, Sawada M, Mabuchi $\mathrm{R}$, Matsumoto T, Nakamura N, Nakamura H, Ninomiya S, Kitagawa J, Kanemura N, Kito Y, Goto N, Miyazaki T, Takami T, Takeuchi T, Shimizu M and Tsurumi H: CHOP or THP-COP regimens in the treatment of newly diagnosed peripheral T-cell lymphoma, not otherwise specified: a comparison of doxorubicin and pirarubicin. Hematol Oncol 35: 163-171, 2017.

3 Sylvester RJ, Oosterlinck W, Holmang S, Sydes MR, Birtle A, Gudjonsson S, De Nunzio C, Okamura K, Kaasinen E, Solsona E, Ali-El-Dein B, Tatar CA, Inman BA, N'Dow J, Oddens JR and Babjuk M: Systematic review and individual patient data meta-analysis of randomized trials comparing a single immediate instillation of chemotherapy after transurethral resection with transurethral resection alone in patients with stage pta-pt1 urothelial carcinoma of the bladder: Which patients benefit from the instillation? Eur Urol 69: 231-244, 2016.

4 Miller AA and Salewski E: Prospects for pirarubicin. Med Pediatr Oncol 22: 261-268, 1994.

5 Tsuruo $\mathrm{T}$, Iida $\mathrm{H}$, Tsukagoshi $\mathrm{S}$ and Sakurai $\mathrm{Y}$ : 4'- $O$ Tetrahydropyranyladriamycin as a potential new antitumor agent. Cancer Res 42: 1462-1467, 1982.

6 Hori H, Kudoh T, Nishimura S, Oda M, Yoshida M, Hara J, Tawa A, Usami I, Tanizawa A, Yumura-Yagi K, Kato K, Kobayashi R, Komada Y, Matsuo K and Horibe K: Acute and late toxicities of pirarubicin in the treatment of childhood acute lymphoblastic leukemia: results from a clinical trial by the Japan Association of Childhood Leukemia Study. Int J Clin Oncol 22: 387-396, 2017.

7 Tsukigawa K, Liao L, Nakamura H, Fang J, Greish K, Otagiri $\mathrm{M}$ and Maeda $\mathrm{H}$ : Synthesis and therapeutic effect of styrenemaleic acid copolymer-conjugated pirarubicin. Cancer Sci 106: 270-278, 2015.

8 Islam W, Fang J, Etrych T, Chytil P, Ulbrich K, Sakoguchi A, Kusakabe $\mathrm{K}$ and Maeda H: HPMA copolymer conjugate with pirarubicin: In vitro and ex vivo stability and drug release study. Int J Pharm 536: 108-115, 2018.

9 Dozono H, Yanazume S, Nakamura H, Etrych T, Chytil P, Ulbrich K, Fang J, Arimura T, Douchi T, Kobayashi H, Ikoma M and Maeda H: HPMA copolymer-conjugated pirarubicin in multimodal treatment of a patient with stage IV prostate cancer and extensive lung and bone metastases. Target Oncol 11: 101-106, 2016.

10 Meredith AM and Dass CR: Increasing role of the cancer chemotherapeutic doxorubicin in cellular metabolism. J Pharm Pharmacol 68: 729-741, 2016. 
11 Mizutani H, Hotta S, Nishimoto A, Ikemura K, Miyazawa D, Ikeda Y, Maeda T, Yoshikawa M, Hiraku Y and Kawanishi S: Pirarubicin, an anthracycline anticancer agent, induces apoptosis through generation of hydrogen peroxide. Anticancer Res 37 : 6063-6069, 2017.

12 Ohnishi S, Mizutani H and Kawanishi S: The enhancement of oxidative DNA damage by anti-diabetic metformin, buformin, and phenformin, via nitrogen-centered radicals. Free Radic Res 50: 929-937, 2016.

13 Mizutani H, Hiraku Y, Tada-Oikawa S, Murata M, Ikemura K, Iwamoto T, Kagawa Y, Okuda M and Kawanishi S: Romidepsin (FK228), a potent histone deacetylase inhibitor, induces apoptosis through the generation of hydrogen peroxide. Cancer Sci 101: 2214-2219, 2010.

14 Drechsel H, Fiallo M, Garnier-Suillerot A, Matzanke BF and Schünemann V: Spectroscopic studies on iron complexes of different anthracyclines in aprotic solvent systems. Inorg Chem 40: 5324-5333, 2001.

15 Stěrba M, Popelová O, Vávrová A, Jirkovský E, Kovaříková P, Geršl V, Simůnek T: Oxidative stress, redox signaling, and metal chelation in anthracycline cardiotoxicity and pharmacological cardioprotection. Antioxid Redox Signal 18: 899-929, 2013.

16 Mizutani H, Oikawa S, Hiraku Y, Murata M, Kojima M and Kawanishi S: Distinct mechanisms of site-specific oxidative DNA damage by doxorubicin in the presence of copper(II) and NADPHcytochrome P450 reductase. Cancer Sci 94: 686-691, 2003.

17 Jewett SL, Rocklin AM, Ghanevati M, Abel JM and Marach JA: A new look at a time-worn system: oxidation of CuZn-SOD by $\mathrm{H}_{2} \mathrm{O}_{2}$. Free Radic Biol Med 26: 905-918, 1999.

18 Burkitt MJ: A critical overview of the chemistry of copperdependent low density lipoprotein oxidation: roles of lipid hydroperoxides, alpha-tocopherol, thiols, and ceruloplasmin. Arch Biochem Biophys 394: 117-135, 2001.

19 Pryor WA and Tang RH: Ethylene formation from methional. Biochem Biophys Res Commun 81: 498-503, 1978.
20 Ralle M, Huster D, Vogt S, Schirrmeister W, Burkhead JL, Capps TR, Gray L, Lai B, Maryon E and Lutsenko S: Wilson disease at a single cell level: intracellular copper trafficking activates compartment-specific responses in hepatocytes. J Biol Chem 285: 30875-30883, 2010.

21 Linder MC: The relationship of copper to DNA damage and damage prevention in humans. Mutat Res 733: 83-91, 2012.

22 Burkitt MJ: Copper--DNA adducts. Methods Enzymol 234: 6679, 1994.

23 Sakano K, Oikawa S, Hasegawa K and Kawanishi S: Hydroxyurea induces site-specific DNA damage via formation of hydrogen peroxide and nitric oxide. Jpn J Cancer Res 92: 1166-1174, 2001.

24 Ogawa K, Hiraku Y, Oikawa S, Murata M, Sugimura Y, Kawamura J and Kawanishi S: Molecular mechanisms of DNA damage induced by procarbazine in the presence of $\mathrm{Cu}(\mathrm{II})$. Mutat Res 539: 145-155, 2003.

25 Murata M, Suzuki T, Midorikawa K, Oikawa S and Kawanishi S: Oxidative DNA damage induced by a hydroperoxide derivative of cyclophosphamide. Free Radic Biol Med 37: 793-802, 2004.

26 Iwamoto T, Hiraku Y, Okuda M and Kawanishi S: Mechanism of UVA-dependent DNA damage induced by an antitumor drug dacarbazine in relation to its photogenotoxicity. Pharm Res 25: 598-604, 2008.

27 Rao VA: Iron chelators with topoisomerase-inhibitory activity and their anticancer applications. Antioxid Redox Signal 18: 930-955, 2013.

28 Gammella E, Maccarinelli F, Buratti P, Recalcati S and Cairo G: The role of iron in anthracycline cardiotoxicity. Front Pharmacol 5: 25, 2014.
Received February 26, 2018

Revised March 20, 2018

Accepted March 28, 2018 